\title{
WHAT IT TAKES TO INNOVATE: THE EXPERIENCE OF PRODUCING AN ONLINE, REAL-TIME CASE STUDY
}

\author{
Dr. James Theroux \\ Flavin Professor of Entrepreneurship \\ Isenberg School of Management \\ University of Massachusetts
}

\begin{abstract}
The case method can be classified as a type of experiential learning because students treat the problem in the case $a s$ if it were real and immediate. Until the Internet there was no practical way for cases to actually be real and immediate. The Internet makes possible instantaneous distribution of cases, and it makes possible their creation in real time. This article describes a recent attempt to use the Internet to bring business reality to business courses, and to facilitate communication among instructors, students, and the case company. It explores the challenges and difficulties involved in producing a new type of case study, and it assesses the feasibility of doing so on a regular basis. The goal of the author is to stimulate a dialog about how the Internet can be used to move forward all of our teaching methods, but especially the one that is prominent in schools of business: the case method.
\end{abstract}

\section{KEYWORDS \\ Real-time Case (RTC), Innovation, Engagement}

\section{INTRODUCTION}

The case method can be classified as a type of experiential learning because students treat the problem in the case as if it were real and immediate. Until the Internet there was no practical way for cases to actually be real and immediate. The Internet makes possible instantaneous distribution of cases, and makes possible their creation in real time. This article describes a recent attempt to use the Internet to bring business reality to business courses, and to facilitate communication among instructors, students, and the case company. It explores the challenges and difficulties involved in producing a new type of case study, and it assesses the feasibility of doing so on a regular basis. The goal of the author is to stimulate a dialog about how the Internet can be used to move forward all of our teaching methods, but especially the one that is prominent in schools of business: the case method.

With the support of the Sloan Foundation, the Kauffman Foundation and the Coleman Foundation, 2001 saw the launch of an innovation in the case method called the real-time case (RTC). A description of what a real-time case looks like and how it works are available at http://intra.som.umass.edu/theroux. An evaluation was conducted on how RTC was received by participating students [1] and by faculty [2].

In brief, a real-time case is a series of weekly case studies all focusing on a single company. The case installments are written as the events being described are unfolding, in real time. Each weekly case focuses on a problem facing a company at that moment, and invites students to solve it. By the end of a 
semester students will have studied the subject company in depth, and will have had some direct contact with the company via the Web. Here is an excerpt from the syllabus of a course centered on a real-time case:

As you read this, the managers of a new high-tech company are striving to achieve the entrepreneurial dream. On a password-protected website (realtimecasestudy.com) you will follow that company, and see their progress week by week. You will be actively engaged with the company, analyzing its problems, and making input. You will be participating, along with 245 other students, in a full-semester, real-time case study.

Unlike traditional case studies, this real-time case will dig deeply into one company during the entire semester. As this moment a case writer is stationed full-time at the case company. Each week the writer will provide us with the information we need to analyze a particular problem or question faced by the company. But our goal is not analysis for its own sake. Instead, we want to go beyond critiquing and make valuable recommendations to the company. The company is counting on us to perform, and we want to deliver.

Results from the 2001 case were positive: students and faculty became supporters of the real-time case, and the concept garnered three national awards for pedagogical innovation [3]. Accordingly, the project director and his funders were motivated to produce a new real-time case in the fall of 2004. The purpose of the second case was to validate results from the first, to expand the use of the case from four universities to eleven, and to try to make improvements in case production.

The subject company for the 2004 case, Company B, was in the business of creating software tools that are used by chip designers. As such, it is part of the highest of high-tech industries. Its employees work in a world that is invisible to the eye but filled with possibilities and complexities. They are on the forefront of new products and technology.

During the first implementation of RTC in 2001109 students at four universities participated in courses in which the real-time case was the main feature. The 2004 program, in which 245 students at 11 universities participated, utilized the same RTC format as the 2001 pilot, but covered a different company as its subject. During both iterations of RTC, students experienced a full-semester immersion in the life of a single company, mediated by the Web. On the Web students read about the company, they saw and talked to the company managers (via video clips and video conferences), they engaged in online chat with company personnel, and they gave feedback to the company about the problems detailed in weekly case installments.

The pedagogical objectives of the case were, first, to bring students to a new level of energy, engagement, and participation. And second, to teach students some lessons that are hard to teach using conventional methods. In particular, the new type of case study, dubbed the "real-time case" (RTC) aimed to 1) instill in students a greater appreciation of the complexity of business decision making; 2) portray a more realistic view of business; 3) take a more interdisciplinary view of problem-solving; and 4) teach all these lessons in a way that is more memorable than the traditional case method.

\section{SCOPE OF THE ARTICLE}

To make an impact on online education and on management education, any pedagogical innovation must pass three tests: 1) students must like it, 2) faculty must find it worth the switching cost; and 3) the innovation must be economical and practical to produce. As cited above, RTC has been well received by 
students and faculty. What remains is to analyze the feasibility of producing a real-time case. That is the subject of this article.

It is one thing to say that the power of the Internet must be brought to bear on one of the mainstays of business education, the case method. But it is another matter to do it. The main purpose of this article is to explore the feasibility of implementing the real-time approach worldwide by describing in detail what it takes to actually produce the material that is consumed by students and faculty. A warning to the reader: It is the judgment of the case production team that the RTC method as developed by the author is not one that is economical to produce on a regular basis by every university. It is however realistic for one or more schools per country to produce a case in a given year and to share it via the web with any number of teaching institutions. Nevertheless, there no doubt are alternative models for producing a real-time case that might yield much of the benefit with a fraction of the cost and effort. We do not speculate on that here, but leave it to the reader to come up with new approaches.

Regarding the production of a real-time case, we investigated questions such as 1) how to select the case company and the case writer, 2) how to choose case topics that bring theory to bear on the real world of company-building, 3) how to manage the relationship with the case company, 4) what methods can be used to engage students and connect them to the case company 5) what kind and amount of work is required of professors utilizing RTC, 6) what skills and attitudes professors must possess to be successful in teaching a real-time case, 7) what course management platform and communication technologies make sense, and 8) what are the costs of producing a real-time case.

\section{INTRODUCTION TO THE 2004 CASE PRODUCTION}

During the 2004 fall semester a consortium of 11 business schools implemented RTC (see Appendix A for list of participating schools).

The professors at the consortium schools all teach courses in entrepreneurship, so entrepreneurship was the subject taught using the real-time case. The area of entrepreneurship dovetails well with RTC because it takes a general management perspective-allowing analysis of problems from any or all of the business disciplines.

The academic director's role was to guide the case writer in the selection and development of topics to be covered in the weekly installments of RTC. Because the academic director is an experienced teacher, he was able to recognize case topics that are appropriate for entrepreneurship courses.

The weekly case installments were documents, sometimes supplemented with video, that are similar in format and writing style to conventional case studies that any major case-writing school might produce. The weekly case was coupled with one or two commercially available "technical notes" (conceptual/theoretical articles) that shed light on the problem addressed in that week's case. The weekly case and the technical note formed the backbone of RTC.

\section{PRE-CASE ACTIVITIES}

Before the discussion about producing case material, a few words should be said about steps that had to be taken in advance: raising funds, selecting the case company, and hiring the case writer. 


\section{A. Raising Funds}

Funds for the 2004 implementation of RTC were received from the Coleman Foundation, the Kauffman Foundation, student payments, and the university that produced the case (name withheld during review) The funds were used to hire a seasoned business journalist to serve as the case writer, to purchase video equipment, to purchase web design and hosting services, and to provide general support. Details on the economics of case production are found below in the section so named.

Assuming a September launch for the case, recruiting for the case company and the case writer had to commence by January of that year. Accordingly, funds had to be in hand by then January so that discussions with companies and writers were not purely speculative. In order for funds to be in hand by January, fundraising began in the middle of the year prior to launch (15 months before students read the first case installment).

\section{B. Selecting the Case Company}

In January 2004 we were looking for a case company that met several criteria. We wanted a company whose industry would appeal to students, and whose product would be fairly easy to comprehend. We preferred a company that was relatively new and venture-capital-financed. Companies like this have so much going on that we felt confident of finding plenty of meaty decisions that would have to be made during our time studying the company.

Because the company would be exposing itself to the class, and perhaps the public, there had to be chemistry and trust between the case company CEO and the academic director, and a strong commitment to staying the course in spite of whatever difficulties might arise. Trust is a key to openness, but even if there is trust, individuals vary greatly in how careful and open they are with information. We were seeking a CEO situated on the open side of the continuum. In general, a CEO whose main experience has been in big corporations would not fit this description. And a company with a staff attorney would also tend to present problems in getting approval for case publication. Finally, because the academic director expected that he would be visiting the company at least once a week, the company needed to be located within two-hour driving distance from the academic director's office.

The academic director found three companies that on a preliminary basis seemed interested and willing to participate. He interviewed four others that declined to participate, primarily for fear of time commitment or confidentiality. Of the "willing three," one was in a high-tech industry. Because a couple of the participating universities included engineers in their classes, and because of the "sexiness" of high tech, we focused our negotiations with COMPANY B.

By selecting COMPANY B as our case company we somewhat inadvertently launched ourselves into a second experiment in pedagogy (the first being the RTC concept itself). That experiment was to see how feasible it would be to teach a case study about a company whose product would be incomprehensible to the layperson. We were intrigued by the challenge of delving into the high tech world. It turns out that some of the students were intrigued as well, while others were less willing to do this. Getting a handle on a new tech lingo took weeks of study before we could begin discussing the business issues of the case company. Some students never got the hang of it. Others loved it.

COMPANY B had received its first venture capital investment in October 2003 just a few months before the Real-Time Case Project had received its funding. As a result, the timing was perfect: the company's funding would last at least until the end of the semester, an important qualifying criterion. COMPANY 
B's CEO and founder, was introduced to the academic director.

It is not clear what motivated the CEO to want to participate with us, but it seems that his interest in education and giving back to society were key factors. He had been a professor of engineering for most of his career, and had not previously worked in private industry, nor had he been a CEO.

COMPANY B did not make its commitment quickly. It took several meetings between the company and the academic director to discuss the project and to brainstorm about the risks and opportunities. Of course the company was worried about things such as embarrassment to individuals, and leaking of company secrets. We assured the company that they would have an opportunity to review material we wrote prior to web posting. And we felt that we could find diplomatic ways of saying things that would protect the dignity of the individual without distorting the business issues at hand. In addition, we developed written "rules of engagement" which guided our relationship (available upon request). And we explained that each student would sign a confidentiality agreement (available upon request).

Before finalizing the engagement, the academic director asked to meet with the staff of fifteen then working at COMPANY B. The CEO dragged his feet about this, and in the end did not want to set up the meeting. He felt it was not necessary. The academic director disagreed, but did not let this stop the process. This should have been a warning sign about the difficulty that we would have in getting the case company's active participation. Another important step before concluding an agreement was approval by the company's board of directors, which was composed of its investors. The CEO assured me that he would do this. It is not clear exactly what he said to the board, but we assume it was adequate. The CEO was quite protective when it came to our case writer contacting the board, but by the end of the semester he allowed a couple phone interviews.

There was no single written document that represented the company's commitment to the project. Instead there was a series of emails from the CEO, plus the written rules of engagement. In future productions of real-time cases, it would probably be a good idea to have some sort of contract. In the present case, the trust and good will between the CEO and the academic director were considered sufficient. This was put to the test in the middle of the semester when the CEO told the academic director that the quid pro quo for his involvement in the case was for the academic director to write a business plan. There were no emails to this effect, and the misunderstanding strained the relationship between the CEO and the case team.

The COMPANY B CEO seemed committed at the outset to making the real-time case a success. However, his willingness to interact with the case team and students turned out to be about half of what the previous case company delivered.

\section{Selecting the Case Writer}

When thinking about the qualifications for a real-time case writer, three main factors came to mind. First, RTC requires a fast, efficient writer who can meet the weekly deadline. One finds that skill most commonly in a professional writer such as a print journalist. The second quality one would like to see is a strong academic knowledge of business. Such knowledge is necessary to be able to separate simple human interest from academically meaningful content. Essentially, the ideal case writer should have the "textbook of business" in his head, allowing him to see how the facts he observes can be organized in a coherent way. Knowing what issues are amenable to analysis using academic theory should guide the writer in asking questions. Such an approach is helpful in creating a case-based course, as opposed to a non-fiction drama such as "The Soul of a New Machine" by Tracey Kidder. A third qualification would 
be the ability to wear well at the case company, sustaining cooperation and access. That ability could be based on several skills and traits. Perhaps an agreeable personality would be sufficient. But more likely business experience, in particular experience as a consultant, when combined with an agreeable personality would make the case writer a welcome presence at the case company's offices. A person who is a respected business specialist would be viewed as a valuable member of the team. How the case writer would share his or her opinions is a delicate matter, but is something that can be managed.

As one can see from the above qualifications, a great case writer is a rare person. How many people can be a business expert, prolific writer, and diplomat-all wrapped into one? On top of all this, the case writer must give over his life to the project for five months: entrepreneurial ventures operate seven days a week, and many hours a day. The case writer has to go where the action is, and that may not leave much room for a personal life during the assignment. On the positive side, most writers and business professionals view the assignment as being a plum because it allows access to the subject that is much deeper than a drop-in interview.

In order to attract a freelance writer with top qualifications it is necessary to pay around $\$ 10,000$ per month in a major urban market. Attracting a high-powered business consultant (who also happens to be an excellent writer) can cost upwards of $\$ 30,000$ per month. Our project did not have the budget to hire a business consultant, so we settled for a freelance writer. And it turned out that $\$ 10,000$ per month was below what the writer was accustomed to earning. He only agreed to take a pay cut because of his interest in the nature of the work, and his relationship with his former boss who was a strong advocate of the RTC concept.

Perhaps an alternative to the high cost of case writers would be to find a professor who could make the case writing project the subject of his sabbatical. Very few professors have the facility with writing to meet the weekly deadlines, and many lack the personality to be a resident observer. However, there may be some who do fit the description, and it would not be too hard to find them so long as it can be done a year or more in advance.

To be able to commence case writing in September, the case writer had to begin work no later than Aug. 1 in order to do background research about the case company and its industry.

The case writing assignment was full-time from August through December. For a high-powered professional to take five months away from whatever they do normally, he or she must do quite a bit of rearranging in his professional life. Even freelancers have projects lined up months in advance. For most prospective recruits, an Aug. 1 start date meant that recruiting conversations had to begin in February, and be concluded around April. Complicating matters, the geographic location of the case company influenced the selection of the case writer, unless the RTC director could have found a case writer who was willing to pick up and move to wherever the case company might be located. Accordingly, the case company recruiting had to go hand in hand with the case writer recruiting.

The 2004 Real-Time Case Project followed the above pattern. Fortunately, the former editor-in-chief of Inc Magazine had agreed to use his extensive network of contacts with writers to find an ideal candidate for us. 


\section{PRODUCING A REAL-TIME CASE STUDY}

\section{A. Choosing Case Topics}

As soon as the case company was selected, the academic director began thinking about possible case topics. That required the academic director to think like a business consultant, whose first step would be to learn about COMPANY B's business. Always respecting the amount of time that the CEO could spare, the academic director sought on his own as much information as was available in the public domain about the company and its industry (chip design). Developing a thorough knowledge of the relevant technology, customers, suppliers and competitors was a necessary prelude to sitting down with the CEO to hear what he considered to be his most perplexing problems or decisions. These problems or decisions formed the basis for case topics. In general, selecting problems identified as priorities to the CEO will be all that it takes to maintain the CEO's attention. But in this case it turned out the CEO held a low opinion of what outsiders could tell him.

Because of the radical nature of the case company's technology, we felt it necessary to devote three weeks to learning the lingo of chip design. Only thereafter could we begin to understand the company's products, markets, and competitors.

After the tech intro, the first case gave enough information about the case company and its industry so that students could form judgments about the company's prospects. The company, believe it or not, did not have a formal business plan, even though a venture capital firm had given them \$6 million. So the case writer pieced together something that looked like the beginning of a plan. Any basic entrepreneurship course deals with the issue of what makes a good business plan. Students were simultaneously introduced to the case COMPANY B by reading its plan, and went through an exercise of critiquing the plan. In the COMPANY B case the COMPANY B business plan we created was enough for students to begin understanding the company's business model.

After the tech intro and the business plan, the academic director, in conjunction with the case writer, had to select case questions/topics where the objective was to solve a problem for the company. As with most startups there were promising case topics in each of the following areas: 1) marketing dilemmas-either figuring out its target market, finding out how best to sell to it, deciding how to price its product; 2) financing dilemmas-every new company worries about where its next round of financing will come from, even if there's money in the bank for the coming year; and 3) every new company is building its staff and has human resource issues about whether the people and the structure are right for the task. COMPANY B was no different.

Some of these case topics were "one and done," meaning that they were not ongoing issues at the company, but matters that could be resolved once and for all. COMPANY B for example, had to make a one-time decision about selecting is headquarters location. Others such as product definition and market segmentation became major themes that were revisited later in the semester, either in the form of "news updates" or in the form of "follow-up cases."

No matter what topic was chosen, a certain amount of planning had to be done to make the production process manageable. It was helpful to know what topic would be covered three weeks hence; that allowed the case writer to be more efficient when doing interviews and data collection. It also reduced the likelihood that a week would arrive without a case ready to be posted. That may sound hard to imagine, but unless there is a good "Plan A" and a good "Plan B", there may be a disaster in case production. It is a good idea to have at least one case always on hand that can be posted in the event of an information- 
gathering failure for the intended case of that week. There were three weeks during the semester (not sequential) when the case writer could not complete a case, but the academic director was able to bail him out by producing a case himself that he had been thinking of.

Planning ahead helped organize the case writing process, and it also gave students some peace of mind. A course based on a real-time case is different from every other course in the following sense: Normally when students arrive at the beginning of the semester they find a syllabus that lays out before them everything that they will be obliged to do. The real-time case asked them to trust the professor that what would appear would be reasonable and interesting. When students began the semester, the first few topics of the real-time case were laid out, even though the content for them was not completed.

Before proceeding to a description of case production, we should mention two more issues related to choosing a case topic. The first has to do with what I call the level of focus. In conventional case courses, most cases aim at what I would call a high level focus, namely big strategic decisions that a company makes only rarely. For example, "What should be our competitive positioning?" or "Should we outsource production?" or "What distribution channels should we use?" The real-time case dealt with these bigpicture, high-level questions. Given the amount of time that students would be spending with the company, (a whole semester rather than a single class period), we hoped to produce a case that drilled down to the smaller decisions that companies make, and to look more at implementation issues than strategic decisions.

For some reason, both the 2001 case and the 2004 case stayed at the high level common to case courses. I am not sure why this is. Perhaps there is more comfort for both students and professors staying at that level. Perhaps the tools for analysis are more available at that level. Perhaps the company was pushing us that way. Since a course in entrepreneurship takes an interdisciplinary and comprehensive view of a company, perhaps a semester is barely enough to deal with all the big picture issues, and not enough time to go to the next level. Whatever the reason, I feel that there exists some undiscovered potential in the case process to delve into the many smaller decisions that make up daily life at a company.

A final issue related to choosing case topics dealt with the tension between two ways of presenting a company: a chronological narrative of what happens versus a relatively random attack on problems to be solved. Telling a company's story as a chronological narrative is probably a good way to draw students in and get them engaged with the company. However, it runs the risk of turning the classroom into a chat session, rather than a chance to practice analytical skills and problem-solving. Compared to the 2001 case, the case of 2004 did a better job at the chronological story. It did so by establishing a "blog" on the case website that almost every day included tidbits about the company’s activities.

Once the academic director picked a topic for the weekly case, he began searching for published articles or book chapters that would guide students' analysis of the case material. In our first production of the real-time case, we were fortunate to negotiate a license with Harvard Business School Publishing to access articles in their vast collection. The cost was \$20 per student. In 2004 we paid on a per-article basis, but the rate was discounted. Most weeks we made two such articles available to students. This provided an alternative to a textbook, and gave students plenty of theory with which to work.

\section{B. Meeting the Weekly Deadline}

Saturday 6:00pm. Come hell or high water we had to post a case and a related technical note (conceptual article) every week at 6:00pm Saturday. Many students asked if we could deliver the weekly material 
sooner; most weeks it was available by Friday night, but Saturday at 6:00pm was the line we could not cross.

\section{Gathering Data on Which the Case is Based}

There were four primary sources of data: 1) internal company documents; 2) published information; 3) notes from meetings at which the case writer was an observer; 4) notes from interviews conducted by the case writer; and 5) opinions from outside experts. Each presented its challenges.

The dream for the case writer and the academic director was to find a document that could be a case unto itself. The most obvious example is the company's business plan. Unfortunately, this did not exist at COMPANY B. Also, most company documents were so highly technical that they could not be read by laymen, so we had to "translate" many of them. We did have one low-tech case: the company needed to find larger quarters, and the process of that search included many documents that any business student could grasp.

When we actually began the case writing process it turned out to be harder than we thought to get access to documents. The case writer had a hard time getting the attention of the CEO to establish procedures for collecting documents and attending meetings. In the end though, we were able to get enough data to produce meaningful cases.

Of course it was much easier to gather published information. The typical info we searched for was about customers, competitors and suppliers. The Web worked well for this, though we almost always needed to supplement Web info with phone interviews. The press of on-site information gathering made it difficult for the case writer to do much external research. Accordingly, external research was handled by research assistants at the academic director's university.

A third source of data was notes from meetings at which the case writer was an observer. The case writer did a pretty good job of attending scheduled company meetings at which several managers were present, but he was not terribly successful at getting into the flow of ad hoc meetings between just a couple of people. Also, we were able to attend only a few meetings with outsiders such as customers, financiers, and suppliers. These were extremely valuable. Part of the problem was our inability to be in two places at one time. For this reason, we recommend that the case writing task be handled by two people in future case productions. There was also a selling job (to get access) that needed to be done with company management, and it was harder than we expected in the 2004 case.

The problem with collecting data as an observer at meetings is that it was much less efficient than conducting interviews. On the other hand, attending meetings was a great way to keep up with the action and to encounter that serendipitous comment which led to a future case topic. Furthermore, the company had only a limited tolerance for spending time one-on-one with the case writer. This again argues in favor of having two case writers, one mainly to attend meetings, and the other to do interviews. To insure proper coordination, the writer attending meetings would have to write up notes daily, and share them with the head case writer and the academic director.

Collecting data via face-to-face interviews with company managers was ideal for the case writer, but less than ideal for the subjects. The pressure to build the company was palpable, and time was of the essence for company managers. Because it was so hard to nab the managers at the office, and because the case writer was reluctant to stay late (when it was easier to get their attention), he resorted to scheduling the 
interviews via telephone, and was sometimes best able to reach the subject via cell phone when he or she was in the car commuting.

We were fortunate to have two or three industry experts who were intimately involved with the case, one at the academic director's university, and the other at Olin College of Engineering. Their technical expertise helped us to evaluate and interpret what we heard at the company.

Before we move on to the process of writing, review, and editing, a word should be said about gathering video data. Our view from the outset was that video could play a valuable role in situations where a picture could say something hard to convey in words. For example, we felt that the personality of the managers could be more accurately divined with video. And the technology employed by the company is much easier to understand with visuals. Unfortunately, we had a hard time getting case company personnel to subject themselves to video.

\section{Writing, Reviewing, and Editing}

Because the case writer was not a business professor, it fell to the academic director to choose the weekly topics and make an outline of the case. This meant that the academic director had to be very informed about the company, by phone and in person. In addition, before the case writer started gathering information related to a topic, each week the academic director provided the case writer a fairly detailed outline of the case. This guided the case writer in formulating interview questions for the company managers.

With an outline in hand, and with all the data gathered, the case writer usually spent Fridays writing the cases, which ranged in length from 3 to 10 single-spaced pages. Of course, this meant he would often have to miss events going on at the company that day, so again we have an argument in favor of hiring an assistant case writer.

The case writer would then forward what he had written to the academic director, who would edit the material, and usually add a page of two of his own to the case. By Friday night, the academic director would forward the draft case to the company CEO for approval. A response usually came before noon Saturday. If the response was a simple "All OK," the case could be posted on the course website immediately. If there were objections or corrections, the academic director would scramble to re-write, and post the case no later than 6:00pm. Only three times during the semester did the CEO request changes, and to us these changes seemed minor.

One might think that meeting the relentless weekly deadlines would be enough for the case team, but in fact much more was going on. Next we will review the "extracurricular activities" that enhanced the realtime case.

\section{Producing Other Materials and Events}

Studying a company in real time opened opportunities for learning and student engagement that can't be imagined in the traditional case context. For example, when using traditional cases there is no company around to which students can pose questions, or submit ideas. In contrast, the real-time case is an event, an experience for students because they are connected to the company. But without technology, the benefits of the real-time nature of the case could not be realized. In this section we will describe how students became connected to the case company and to each other via communications technology. 
The most obvious way to connect students to the case company is through standard communications tools such as video conferences, phone conferences, and online chat. We employed each of these techniques at least once.

\section{Video Conference}

Our first thought was to start things off with a bang by holding a video conference during the very first week of the semester. We then decided that students would get more out of a conference if they had some background knowledge of the company's technology, so we waited until week four. By that time students had read the company's business plan, and had learned about the technology of chip design.

It turned out that we could not find a practical way of have an interactive video conference at eleven locations, so we settled for a taped video interview with the CEO. At the end of the semester all eleven campuses had access to a live voice conference on the web with the CEO using a service called Elluminate (IP telephony). Because of the availability of Elluminate, we did not use conventional phone conferencing, as we had done in 2001.

\section{Online Chat}

Another method for connecting students directly to the case company was online chat. We announced that for one hour on a particular night a COMPANY B manager would be available online to answer questions. This was done twice during the semester. As with other mediated interactions, the chats took place outside of class time. This meant participation was a fraction of class attendance, averaging around $10 \%$. In the future we see no reason not to have at least an online chat session every week. If we assume that there are seven managers to handle the task, each manager would have to show up on line twice during the semester, not an undue strain.

\section{Guest Speakers}

The bulk of the "extracurricular" materials and activities organized by the academic director and described above fall into the general category of connecting students to the case company and facilitating communication. The case team felt that it could do even more than this to enrich the students' learning. One way was to bring guest speakers into the classroom.

Because the case company's technology was so challenging, faculty at several of the RTC sites found chip design experts to speak to their students. At the academic director's university, a professor of computer engineering actually sat in on every class, and gave invaluable insights into the case company. At Olin College of Engineering a professional chip designer sat in on each class, and was willing to provide input to the case production process

In addition to arranging industry experts to speak in classes, the professor at Clark University was able to get the CEO to visit his classroom.

\section{Processing Student Questions and Recommendations}

Video, phone, and chat are ways of directly connecting students to the company. But there are important indirect methods as well. There are two main goals of this indirect connection. The first is to convey student recommendations to the case company and the second is to answer the many student questions about the company that were not answered directly. As mentioned above, only a small portion of each 
class participated in direct communication via video, phone, and chat. Also, these direct communications events did not occur weekly, leaving extended periods when many questions occurred to students. One of the best ways of sustaining student interest and engagement is to answer questions quickly when they arise. Students could post questions on the website, and the RTC staff would answer them. One of the academic director's research assistants spent about 10 hours a week on this job.

\section{Processing Student Questions}

Students at (name of the academic director's university withheld) had no difficulty getting answers to their questions, because their professor was also on the case writing team. However, the professors at the other schools did not have any more information about the case than did their students, so students had to look elsewhere for answers.

The logical way for students to get answers was to submit them on the case website. The case writing team either knew the answer right away, or was be able to find the answer from the case company. It then was posted on the website where everyone had access.

In the 2001 production of the real-time case the system to do this was not in place. Questions came to the academic director from a variety of sources - such as weekly papers from all the schools, conversations, and emails. Sometimes he tried to answer the individual student, and somewhere past the mid-point of the semester he created a file on the website that contained all the questions he had fielded, along with some explanations of other topics he felt might be helpful. An announcement was made to all students about this FAQ-type file, but there was never a proper, expeditious, highly visible and systematic way of processing questions.

In the 2004 production the case staff (a teaching assistant of the academic director) fielded student questions through the RTC website. In the center of the Course Content page students had a link named "Post Your Questions Here" from which they then could post new questions, post replies to other students' questions, and review responses from the case staff or other students. Over the course of the semester 22 distinct threads were created with a total of 34 replies, originating from 10 different source schools. The questions spanned a period of about 10 weeks starting the last day of September and ending the second week of December.

The case staff adhered to a 24-hour response time goal. Most questions were addressed in that period while those that required more research were given a preliminary reply and then a follow-up response when more information was gathered. Questions varied in complexity and some of the sources for response information included experts and professors in the field, written books and resources, online databases, the Internet, and a US patent official.

Overall, the process of addressing questions was a success. It was useful to have a single person in charge of finding and posting responses to student questions; to have a good writer who can deal with the attimes ambiguous or complex questions; and to maintain a standard of short response turnaround.

\section{Processing Student Recommendations}

One of the fundamental elements of the real-time case concept is the communication of students' ideas to the company. This sets RTC apart from the traditional case method, and it has the potential to increase students' motivation. A system was set up to provide student input to the case company. The system 
agreed upon by all the RTC teachers was that a student (or student team) would be assigned each week to write a summary of the class's analysis of that week's case. This was a valuable exercise for the "reporter" for the week because it required the person to sort out an array of views and to distil them into a coherent presentation.

The summary papers from each class at the schools were then forwarded to the academic director. The papers were read by one of the case team research assistants who would evaluate them from a factual standpoint. He would give the author feedback on whether the paper contained any false assumptions or statements. Our idea was that this feedback would be valuable to students; it would not be as valuable as feedback from the company, but at least we could maintain contact and be sure students were not getting too far off track. After review and feedback, the papers were posted on the website, where students from all the schools could compare and contrast. Although this sounds like a good idea in theory, we have little feedback about whether students made use of it.

Once the academic director read the papers he had to decide whether to forward them to the case company. Unfortunately the CEO discouraged this. In general the papers did not get sent to the company, and both sides lost out: the company was getting less than it hoped in the way of good advice, and the students were feeling less connected to the company and less valuable as consultants. The papers were accessible to the CEO on the course website.

\section{E. Facilitating Communication Among Students}

In addition to connecting students to the case company, the real-time aspect of the case meant that students at a number of schools simultaneously studied the same thing. And because all the students used the same website to receive case material, the case team theorized that there would be opportunities for new types of cross-university communication among students. We still believe this is true, but more time and thought will have to go into the design of mechanisms to encourage it. From student surveys we learned that students are eager to have this kind of communication.

The most obvious mechanism for inter-school communication would be chat rooms or message boards on the course website. Another good idea would be to have students post on the website any research papers they might write about the case company. These ideas are examples of cooperative activity centered on an interest in the case.

\section{Using Competition Among Universities as an Educational Tool}

Another approach to both facilitate interaction among students and connect students to the case company was to sponsor competitions among the schools. Two such competitions were organized by the academic director, and it turned out to be an example of the intense student engagement and learning that is possible when a case study is developed in real time. The first competition was to analyze one of the weekly cases. The second was to come up with a name for the company's product.

During the week of Oct 17, students at all eleven universities participated in a contest to see who could write the best paper about how the case company should price its product. Students were free to submit the paper on an individual basis or as a team. The professor from each university picked the best paper from his class and submitted it to the case company for final judging. The prize was $\$ 500$. Unfortunately the CEO was very slow in picking a winner (it took until the end of November), and gave little feedback on why he chose the winner. This was frustrating to a number of the students. Nevertheless, competition was keen and students worked hard to win, according to reports from professors. 


\section{Student Research Papers}

The professor at any of the schools could have required his or her students to do a research paper dealing with some aspect of the case company. This would be in addition to the weekly case discussions. Several of the schools did so. All except the academic director's university were incorporating the real-time case into a course that included other material. This left little time for a case-related research paper. In the future, it may make sense to arrange a course where the case is the sole focus; in that situation a research paper could be fit in. Assuming that these papers would be shared with all students via the website, the amount of useful information available to students in analyzing the weekly cases would expand exponentially.

\section{Trade Shows}

As mentioned above, attending a trade show is one of the best ways to quickly get oriented to an industry. Some way should be found for the case writer to attend a trade show before the case commences, and a way should be found to get students connected to one during the semester. Of course, not all the students could attend, but some way could be found to deputize a few students to attend and gather information on behalf of the others. There was a single trade show for our case company, and unfortunately students could not attend because it occurred before the semester began. However, the case-writing team was able to attend. During the 2001 case, students competed to win an all-expenses-paid trip to a trade show at which the case company was in attendance. This yielded benefits for the case (Kilbane, Theroux, 2004).

\section{F. Producing Materials and Communications for Faculty}

All of the above activities by the case team were directed at enhancing the educational experience of students studying the real-time case. But the real-time case presented some unique challenges to the professors teaching it, and the case team had to consider their needs as well.

Unlike most courses, the professor did not have "the answers" before the students did. Professor and student got the same material at the same time. The good news is that this had the potential to forge a relationship between the two in which students and faculty became partners in executing the task of advising the case company. The bad news is that this partnership may not be comfortable to some professors, especially those with a strong need for control, or a strong need to impress, or a weak sense of security. Probably such professors would be better off not teaching a real-time case. But what could be done for a professor ready for the challenge and excitement of the new kind of teaching? And what can these professors contribute to the multi-campus RTC event?

Because the first production of the real-time case consisted of only four universities, one of which was the home of the academic director, it was possible for the academic director to maintain a personal dialog with the other three professors who utilized the real-time case in their classrooms. In general the academic director spoke on the phone or exchanged an email with the other professors every two weeks. But the 2004 case included 11 sites, and it was not possible for the academic director to give much individual attention, though he certainly tried.

Instead of individual attention the academic director sent the same email to the professors, usually one per week. What was the nature of this communication? In general the academic director shared insights with the other professors that he had gained about the company, but which were not written about in the weekly cases. Often this consisted of "human interest" tidbits that were too personal to be broadcast on the web. The academic director also shared his views about how to analyze the cases. 
In sum, there was some informal, ad hoc support of the professors teaching the case, but nothing systematic. This was simply because the academic director lacked the time or resources. Most weeks, the case team was able to produce PowerPoint slides that summarized the technical notes that accompanied the cases. A full report on faculty experience in 2001 is published elsewhere [2]. A report on the faculty experience in 2004 is forthcoming.

\section{G. Technology Issues}

Nearly all of the communications described above were mediated. In the following section we review the challenges and benefits this presented. The RTC course content resided on a web "course platform" called Moodle (similar to Blackboard or WebCT). Moodle is an open access platform that is free. The following section discusses the technical issues faced during the course and the resolutions to these problems that the RTC team came up with.

\section{Web Hosting Services}

Web hosting service can be understood as the following: The RTC team produced text, video and PowerPpoint files that had to physically reside on a server; the information traffic to and from the server had to be managed, and all the technical problems that could affect that server (i.e. slow it down or shut it off) had to be managed. The web hosting company does all of these things. In addition, since RTC used Moodle as its course software platform, the web hosting company was also responsible for downloading and configuring Moodle to their server, enabling us to use the Moodle software to build our site.

Our initial web hosting company was Net Mondo. Net Mondo's down time turned out to be much higher than we desired, and its method of handling problems was through internet "complaint tickets" as opposed to phone contact. The turnaround time for "completing tickets" or fixing the problem was less than optimal for a course such as RTC. The RTC team decided to seek service from another web hosting company, initially as a backup for when the Net Mondo site was down. We chose Remote-Learner.net as this new hosting service. The staff at Remote-Learner.net was available by phone and was much more responsive to our needs. The downtime was less and speed of download was faster.

After experiencing the better quality of hosting by Remote-Learner.net, the main site was switched from realtimecasestudy.net using Net Mondo to realtimecasestudy.com using Remote-Learner.net. This was done by configuring the Net Mondo site to automatically link to the Remote-Learner.net site.

The experience gained by the RTC team regarding how to deal with web hosting companies and the knowledge that Remote-Learner.net provides quality service will serve future RTC teams well. It is likely that any future RTC courses put together by (University name) will use Remote-Learner.net

\section{Internet Course Software: Moodle}

Many software programs exist which purport to facilitate easy and effective internet course creation, and there likely will be more such programs in the future. These programs vary in their cost, ease of use, features, and presentation. In the months before the launch of the course, the RTC team evaluated several of these, finally deciding upon Moodle. Moodle had the following benefits: 1) it is free, 2) a number of web-hosting companies claim to know to host Moodle, 3) its layout and presentation is compatible with the needs of the RTC, and 4) the layout and details of the pages can be easily edited without requiring any programming knowledge. The drawbacks are: 1 ) in some instances, small details such as the wording of pre-set headings could not be changed, and 2) some features the RTC team would have desired did not 
exist, i.e. Wiki and videoconferencing capabilities. Wiki is a type of page that is mainly text and in our case would serve as a medium for asynchronous collaboration between students. For example, work groups could have password-protected Wiki pages where they work from home but on the same page in an effort to complete the assignment. Wiki could also be used to facilitate online discussions spanning all involved schools. Videoconferencing capabilities would be used for videoconferencing.

It is likely that Moodle could be used successfully for future RTC productions. Moodle is an open source program that is constantly being updated with new features. Future releases of Moodle may contain new features that improve the student experience. However, since many other competing programs exist, the RTC team may discover a new program that serves its needs better. Features that have the potential to greatly enhance the RTC experience are those that facilitate easy and effective interaction of students through the site.

\section{Student Payments for the Course}

Students at all participating universities paid \$60 each for the RTC material. To collect the money the RTC staff set up a Paypal account, and also set up a special e-mail address. Directions on how to pay were included in a link on the case website. When a student paid for the course, an e-mail notification was sent to the case e-mail address. In this way the RTC team was able to track who had paid. However, in some instances parents or spouses of the students made the payment on behalf of the student. When this happened, the RTC team would get the name of the parent or spouse and not the name of the student. This required the RTC team to e-mail the paying party to ascertain the name of the student. Teams involved in future productions of RTC should pre-empt this problem. The most likely solution, if possible, would be to include an additional field in the Paypal form for the student name.

\section{Email Announcements to the Students}

Email announcements sent to all students were created by posting a new message in the section of the case website called "Latest News". The email received by the student includes only the students address in the "to:" line, maintaining the confidentiality of the students' addresses. (Each student was given the option when registering to make his/her email address available to the other students or hidden from the other students.) However, some students did not enter valid e-mail addresses when filling out their profile. This resulted in delivery failure errors. The students' professors were contacted and asked to have the student fill in their correct e-mail address.

\section{Video Production}

Video clips were created by the case writer using a digital video camera. The camera could later be plugged into a computer and Adobe Premiere was used to edit the clip and convert it into a file format compatible with running on a streaming server. Since video files are so large, using a streaming server helps the end user view the video more easily. The Windows Media program downloads a certain amount of the file ("buffering") and then starts to play the video. As the video plays, the rest of the video file is downloaded. This streaming file originated from a server at the academic director's university. The internet address for the file on the streaming server was linked to the case website. The student would click on the link and a new screen would pop up where the video would download and play.

\section{H. Maintaining Relations with the Case Company}

No review of what was learned about producing a real-time case would be complete without mentioning the process of maintaining the good will of the case company. This job fell upon the academic director 
and the case writer.

It is essential to start the case production process with trust and confidence between the CEO and the academic director. The 2004 case began with what the academic director thought to be a strong relationship with the CEO. That relationship was then extended to the case writer, who had his desk in the office of the CEO. Unfortunately, by the end of the semester the relationship declined, as mentioned above.

From the outset there were clear groundrules for the engagement (available upon request). The groundrules dealt with the case writer's access to information, approvals required for talking with outsiders (customers, supplier, media, investors), confidentiality expected of students (available upon request), the approval process for unclear matters, the procedure for approving material posted on the course website, and space usage privileges for the case writer. These guidelines were followed carefully, and seemed to cover everything.

Although the academic director's university and the case Company Both made a commitment to proceed with the project, the academic director did not want to take for granted the company's cooperation. Accordingly, he took a number of steps to keep the cooperation strong. That cooperation started and remained strong in the 2001 case. In contrast, it was difficult to interact on a casual basis with the managers of the 2004 case company. The academic director tried whenever possible to make small talk and get to know the company's managers. And he would periodically ask them how they felt about the process of working with the case writer. The managers did occasionally have gripes. ("Why is he always trying to do interviews?”) Attempts were made to fix things.

\section{The Case Company's Evaluation of the Experience}

One of the assumptions behind the real-time case is that the case company will benefit from participating in the case; it won't be a one-way street in which the students and universities get all the benefit.

Accordingly, an important component of the project evaluation would be a careful analysis of the case company's perspective on the case study experience. However, that plan changed when, near the end of the semester, it became apparent that the case company CEO was peeved, and he did not want to participate in any type of exit interview or evaluation. It appears that the CEO was upset that he did not get a finished business plan out of the RTC process. He believed, mistakenly, that a business plan was the quid pro quo for his participation.

\section{J. The Economics of RTC}

The greatest cost in producing the RTC is that of hiring a case writer. Gathering data for the real-time case requires that this person be present at the case company around 50 hours per week over a six-month period. The case writer gathers the data during all types of meetings while observing the company doing its business. The case writer can also take company managers away from their normal activity and schedule interviews. Obviously, scheduling interviews must be held to a minimum so that the case production process does not become too large a time burden on the company. The writer must have the skill to produce high quality material on a weekly deadline, the knowledge of business to sort out the wheat from the chaff, and a personality that can wear well on a wide variety of managers at the case company. 
Such a person does not come cheap. In general a person meeting these criteria will be a mature professional with years of experience. Since many professors and students count on the writer to deliver a weekly case, in our judgment that it is not realistic to hire an unproven person such as a doctoral student. The ideal person would be a McKinsey consultant who is also an excellent writer. The anticipated cost would be over \$30,000 per month. But other professionals, including free lance journalists, professors on sabbatical, or less prominent consultants might also do the job reasonably well. The going rate for such professional is around \$10,000 per month.

In addition to funding the case writer $(\$ 60,000)$ money is needed to conduct video conferences $(\$ 8,000)$, phone conferences $(\$ 3,000)$, digital video equipment and software $(\$ 4,000)$, student research assistants $(\$ 20,000)$, travel $(\$ 4,000)$, and copyright fees for conceptual articles provided on the Web to students (\$30/student). Of course, expensing the time of the academic director is also required. In the 2001 and 2005 cases the academic director received no compensation above his usual faculty salary.

It is certainly possible to produce a real-time case for less money than described above. And that would be desirable if the goal would be for many schools to produce such cases for their own students (not shared with other schools). The benefit of fewer schools per case is that the individual student might feel a closer connection to the case company. But we feel that in the early years of the real-time case that it makes more sense for one or two schools per year to produce a case with a high standard of quality (and cost). The Web makes it possible for an unlimited number of students and faculty to benefit from the effort of a handful of professional case producers.

The model of "few cases-many schools" also may be necessary to make the case production process independent of foundation support. If enough schools (around 70) adopt the case each year, student fees would be sufficient to cover the cost of producing the case.

\section{SUMMARY AND CONCLUSIONS}

The real-time case study was provided to entrepreneurship students at eleven schools in the US, Canada, and Puerto Rico. The majority enjoyed that experience and found it superior to what they were accustomed at their school. Instructors as well valued the experience and are ready to sign up for the next case. Weighing against these positives is the fact that the quality of students' experience with the case was diminished by two factors: the extraordinarily challenging nature of the case company's product, and the less-than-satisfactory cooperation of the case company CEO. We have learned lessons that will help us realize the potential of the real-time case concept. 


\section{APPENDIX A}

\begin{tabular}{|lll|}
\hline Site & Student Profile & Institution \\
\hline Site 1 & 13 MBA students & Clark University \\
Site 2 & 14 Undergraduate senior business majors & Univ. of Northeast Oklahoma \\
Site 3 & 14 High school juniors and seniors & Wilbraham-Munson Academy \\
Site 4 & 15 Undergrad engineering and business majors & Loyola-Marymount University \\
Site 5 & 25 MBA and undergraduate engineering students & Olin College/Babson College \\
Site 6 & 28 MBA, executive, and undergrad & Univ. of Mary-Hardin Baylor \\
Site 7 & 7 MBA students & Inter-American University (Puerto Rico) \\
Site 8 & 26 MBA students, part-time and full-time & Penn State Univ. \\
Site 9, Section 1 & 40 Full-time undergraduate students & UMass Amherst \\
Site 9, Section 2 & 13 Full-time MBA students & UMass Amherst \\
Site 10 & 34 MBA students, 4 were executives & Univ. of New Brunswick (Canada) \\
Site 11 & 16 Undergrad business majors & Univ. of Tampa \\
\hline
\end{tabular}

\section{REFERENCES}

1. Theroux, J. and C. Kilbane. The Real-Time Case Method: a New Approach to an Old Tradition. Journal of Education for Business: Jan./Feb., 2004

2. Kilbane, C.; J. Theroux, J. Sulej, B. Bisson, D. Hay, and D. Boyer. The Real-Time Case Method: Description and Analysis of the First Implementation. Innovative Higher Education 29(2): Winter 2004.

3. The U.S. Association for Business and Entrepreneurship (USASBE), the largest organization of professors of entrepreneurship, named the real-time case study as the Pedagogical Innovation of the Year in 2002. Sloan-C, a leader in the study and dissemination of best practices in online education selected the real-time case for "Best Practice for Student Satisfaction in 2002." The US Distance Learning Association (USDLA) is one of the three largest organizations focused on the development and improvement of online learning. In 2003 they designated the real-time case study for the Excellence in Distance Teaching Award.

4. Theroux, J. and C. Kilbane. The Real-time Case Method: The Internet Creates the Potential for New Pedagogy. In J. Bourne and J. C. Moore (Eds.), Elements of Quality Online Education: Engaging Communities, 31-40. Needham, MA: The Sloan Consortium, 2005.

\section{ABOUT THE AUTHOR}

James Theroux, Ph.D., is a UMassOnline professor of business. He is a recipient of the United States Distance Learning Association (USDLA) Excellence in Distance Teaching Award and of the Sloan Consortium Excellence Award. 